\section{Differential display analysis of Porphyromonas gingivalis gene activation response to heat and oxidative stress}

\author{
Shelburne CE, Gleason RM, Coulter WA, Lantz MS, Lopatin DE. Differential display \\ analysis of Porphyromonas gingivalis gene activation response to heat and oxidative stress. \\ Oral Microbiol Immunol 2005: 20: 233-238. (C) Blackwell Munksgaard, 2005.
}

Background/aims: The etiologic relationship between periodontitis and Porphyromonas gingivalis is attributed to the ability of the organism to express a variety of virulence factors, many of which are cell surface components including lipopolysaccharide and arginine-specific cysteine proteases (Arg-gingipains, RgpA, and RgpB). P. gingivalis responds to the stress of rapid elevation in temperature by activating a set of genes to produce heat shock proteins that mediate the effects of sudden changes in environmental temperatures by repairing or eliminating cellular proteins denatured by that stress.

Methods: We used restriction fragment differential display (RFDD) to identify and measure the genes expressed by surrogates of environmental stresses, heat and oxidative stress. The results were then confirmed using quantitative reverse-transcription polymerase chain reaction.

Results: We selected 16 genes differentially induced from over 800 total expression fragments on the RFDD gels for further characterization. With primers designed from those fragments we found that $\mathrm{a}+5^{\circ} \mathrm{C}$ heat shock caused a statistically significant increase in expression compared 12 of 18 untreated genes tested. The exposure of $P$. gingivalis to atmospheric oxygen resulted in statistically significant increases in five of the target genes. These genes are likely involved in transport and synthesis of components of the lipopolysaccharide biosynthetic pathway important in anchoring the Arg-gingipains required for virulence-related activities.

Conclusion: These results emphasize the need for studies to measure the coordinated responses of bacteria like $P$. gingivalis which use a multitude of interrelated metabolic activities to survive the environmental hazards of the infection process.
C. E. Shelburne ${ }^{1,2}$, R. M. Gleason ${ }^{2}$, W. A. Coulter ${ }^{3}$, M. S. Lantz', D. E. Lopatin ${ }^{1}$

${ }^{1}$ Department of Biologic and Materials Sciences, School of Dentistry, The University of Michigan, Ann Arbor, Ml; ${ }^{2}$ BioMaterials Technology Center, 3M Company, St. Paul, MN, USA; ${ }^{3}$ Oral Research Centre, School of Dentistry, Queen's University of Belfast, Belfast, Northern Ireland

Key words: differential display; environmental stress; gene activation; gingipain; heat shock; lipopolysaccharide; oxidative stress; Porphyromonas gingivalis; periodontitis; quantitative polymerase chain reaction

C. E. Shelburne, The University of Michigan, Department of Biologic and Material Sciences, School of Dentistry, 1210

Eisenhower Place, Ann Arbor, Michigan 48108, USA

Tel.: + 7349750946 ;

fax: 734-975-9329;

e-mail: ceshelbu@umich.edu

Accepted for publication January 31, 2005
The etiologic relationship between periodontitis and Porphyromonas gingivalis is attributed to the ability of the organism to express a variety of virulence factors that include proteolytic enzymes (8), adhesins (30), and fimbriae antigens (17). In addition, $P$. gingivalis has a repertoire of gene products that can interfere with the immune response of the host (43). This includes paralysis of immune cells by extracellular vesicles (14) that contain many of the cell surface components of whole cells, including lipopolysaccharide and gingipains. $P$. gingivalis also expresses a superoxide dismutase which contributes to the species' mild aerotolerance (23).

$P$. gingivalis responds to the stress of a rapid elevation in temperature by activating a set of genes to produce heat shock proteins (22). These proteins mediate the effects of sudden changes in environmental temperatures and help the cells acclimatize to elevated temperatures, and are among the most common of the immunodominant antigens expressed by bacteria $(21,24,42)$.

The objective of these experiments was to investigate genes differentially expressed when $P$. gingivalis was challenged by either a $+5^{\circ} \mathrm{C}$ temperature shift or the oxidative stress of growth in atmospheric oxygen levels or hydrogen peroxide. Here we describe the use of restriction fragment 
differential display (RFDD), a modification of the cDNA amplified fragment length polymorphism technique (3), to identify and measure the expression of genes by heat and oxidative stress, surrogates of environmental stresses. Exposure of $P$. gingivalis to atmospheric oxygen resulted in statistically significant increases in five of the 18 target genes tested and 13 were increased after a $+5^{\circ} \mathrm{C}$ heat shock. These genes are likely involved in transport and synthesis of components of the lipopolysaccharide biosynthetic pathway important in anchoring $P$. gingivalis Arggingipains, which were also up-regulated, required for virulence-related activities.

\section{Methods \\ Bacterial growth}

P. gingivalis strain ATCC 33277 was obtained from the American Type Culture Collection and maintained by weekly transfer on PRAS Brucella agar plates (Anaerobe Systems, Morgan Hill, CA, USA) in an anaerobe chamber (Coy Manufacturing, Grass Lake, MI, USA) at $37^{\circ} \mathrm{C}$ in $5 \%$ hydrogen, $10 \%$ carbon dioxide, and $85 \%$ nitrogen. Broth cultures were grown in a modification of BHTS (34) without serum and supplemented only with hemin $(5 \mathrm{mg} / \mathrm{l})$ and menadione $(5 \mu \mathrm{g} / \mathrm{l})$. Measurement of the optical density of broth cultures at $600 \mathrm{~nm}\left(\mathrm{OD}_{600}\right)$ was used to estimate the concentration of bacteria.

\section{Stress induction of $\boldsymbol{P}$. gingivalis in vitro Stress induction}

Cultures used throughout these experiments were grown to standardized densities $\left(\mathrm{OD}_{600}=0.20\right)$ because some stress genes are growth phase-induced (20). Cultures were then either heated to $42^{\circ} \mathrm{C}$ for $30 \mathrm{~min}$ or treated with hydrogen peroxide at a final concentration of $3.2 \mathrm{~mm}$ for $20 \mathrm{~min}$ anaerobically or transferred to a $50 \mathrm{ml}$ tube and shaken at $37^{\circ} \mathrm{C}$ for $30 \mathrm{~min}$ in normal atmosphere (28). Untreated cultures grown were used as controls.

\section{Production of cDNA RNA extraction}

One $\mathrm{ml}$ of bacterial culture was combined with $2 \mathrm{ml}$ of RNAProtect ${ }^{\mathrm{TM}}$ (Qiagen, Valencia, CA, USA), incubated at $37^{\circ} \mathrm{C}$ for $5 \mathrm{~min}$ and centrifuged at $3700 \mathrm{~g}$ for $5 \mathrm{~min}$. The supernatant was removed and $100 \mu \mathrm{l}$ of TE buffer with $1 \mathrm{mg} / \mathrm{ml}$ lysozyme (Sigma, St. Louis, MO) added for an additional $2 \mathrm{~min}$. A volume of $350 \mu \mathrm{l}$ of bacterial lysis buffer RLT (Qiagen) was added to each tube, gently mixed, followed by $250 \mu \mathrm{l}$ of $100 \%$ ethanol. The lysate was then transferred to an RNAeasy ${ }^{\mathrm{TM}}$ mini column (Qiagen) and the DNA digested on the column using an RNAase-Free DNAse Set (Qiagen) according to the manufacturer's instructions. The RNA was then isolated using an RNAeasy ${ }^{\mathrm{TM}}$ Total RNA kit (Qiagen). RNA was eluted into $30 \mu \mathrm{l}$ of RNAse-free water, and the amount of RNA estimated by determining the absorbance at $260 \mathrm{~nm}$.

\section{cDNA synthesis}

cDNA synthesis and subsequent differential display were performed using a display Profile Prokaryotic Kit using $0.5-1.0 \mathrm{pg}$ total RNA, $\mathrm{N}_{8}$ random primers, and display THERMO-RT ${ }^{\mathrm{TM}}$ according to the manufacturer's instructions (Azign Bioscience, formerly Display Systems, Copenhagen, Denmark). For quantitative reverse-transcription polymerase chain reaction-PCR reactions, the total RNA from each sample was reverse transcribed using a SuperScript ${ }^{\mathrm{TM}}$ First-Strand Synthesis System and random hexamers (Invitrogen, Carlsbad, CA, USA).

\section{Restriction Fragment Differential Display}

RFDD is similar to standard differential display methods with the exception that after converting the mRNA to DNA, restriction fragments are generated by digestion with the $T a q \mathrm{I}$ restriction enzyme $(12,13)$. Aliquots of the restriction digest are then combined with 32 different 20 -base PCR primer sets of random sequence except the forward primer of each set begins with a sequence of 4 bases homologous with the TaqI restriction sites. Therefore, amplification of each random fragment always begins at a TaqI site. After amplification, each of the 32 tubes is analyzed on polyacrylamide gels. The results of the different treatments are 'displayed' next to each other for each set of primers, and the results compared (seeFig. 1). Specifically, the cDNA was digested with TaqI restriction enzyme and a ligation mixture containing T4 DNA ligase, ATP and an adaptor sequence, binding at the TaqI restriction site, was added to the digestion mix and incubated for an additional $3 \mathrm{~h}$ at $37^{\circ} \mathrm{C}$. The ligated fragments were then amplified using a 'touchdown' PCR scheme. A mixture containing forward primer, displayTAQ DNA polymerase, ligated cDNA, dNTP mix solution, 10× display TAQ FL reaction buffer and one of 32 display PROBES ${ }^{\mathrm{TM}}$ (reverse primers,
Azigen, Copenhagen, Denmark) were combined in each of 32 wells in a 96-well PCR plate. There were 10 cycles of touchdown PCR $\left(94^{\circ} \mathrm{C}, 30 \mathrm{~s} ; 60^{\circ} \mathrm{C}\right.$ to $55^{\circ} \mathrm{C}$ with $0.5^{\circ} \mathrm{C}$ decrements in each cycle, $30 \mathrm{~s} ; 72^{\circ} \mathrm{C}$, 1 min) followed by 25 cycles of constant annealing temperature $\mathrm{PCR}\left(94^{\circ} \mathrm{C}, 30 \mathrm{~s}\right.$; $\left.55^{\circ} \mathrm{C}, 30 \mathrm{~s} ; 72^{\circ} \mathrm{C}, 1 \mathrm{~min}\right)$.

\section{Polyacrylamide gel electrophoresis analysis of RFDD}

Samples of each RFDD reaction were loaded into the wells of a $12.5 \%$ polyacrylamide precast gel (ExcelGel DNA, Amersham Pharmacia Biotech, Piscataway, NJ, USA) electrophoresed and silver stained (PlusOne DNA Silver Staining Kit, Amersham Pharmacia Biotech). Adjacent wells containing unstressed, heat stressed or oxidative stressed bacteria were then compared and PCR fragments with altered expression noted. Bands were cut out of the gels and extracted into $20 \mu \mathrm{l}$ volumes of water.

\section{Cloning and sequencing of differential display products}

To identify the expressed genes, DNA from bands of interest were cut out of the polyacrylamide gel and re-amplified using the same display PROBES ${ }^{\mathrm{TM}}$ used in the RFDD amplification. The PCR products were checked for appropriate size on $2 \%$ agarose and cloned using a $\mathrm{TOPO}^{\mathrm{TM}} \mathrm{TA}$ Cloning Kit (Invitrogen). The cloned gene fragments were sequenced at the Advanced Genetics Analysis Center, University of Minnesota. Sequences were evaluated using BLAST (2) searches at The National Center for Biotechnology Information (NCBI) web site (http:// www.ncbi.nlm.nih.gov), The Institute for Genomic Research (TIGR) Comprehensive Microbial Resource database web site (http://www.tigr.org/tigr-scripts/CMR2/CMR HomePage.spl), or the Los Alamos National Laboratory, Bioscience Division Oral Pathogen Sequence Database web site (http://www.stdgen.lanl.gov/cgi-bin/right.cgi? subdir $=$ oralgen).

\section{Quantitative PCR}

PCR primers for each target gene at $50 \mathrm{nM}$ in SYBR Green PCR buffer were added to a 96-well assay plate. Target cDNA $(0.5 \mu \mathrm{l})$ from treated or control cultures was added to triplicate wells, heated at $95^{\circ} \mathrm{C}$ for $15 \mathrm{~min}$, then 40 cycles of $95^{\circ} \mathrm{C}$ for $30 \mathrm{~s}$ followed by $60^{\circ} \mathrm{C}$ for $60 \mathrm{~s}$ using an iCycler (Bio-Rad Laboratories, Hercules, 


\section{PRIMER SET NUMBER}

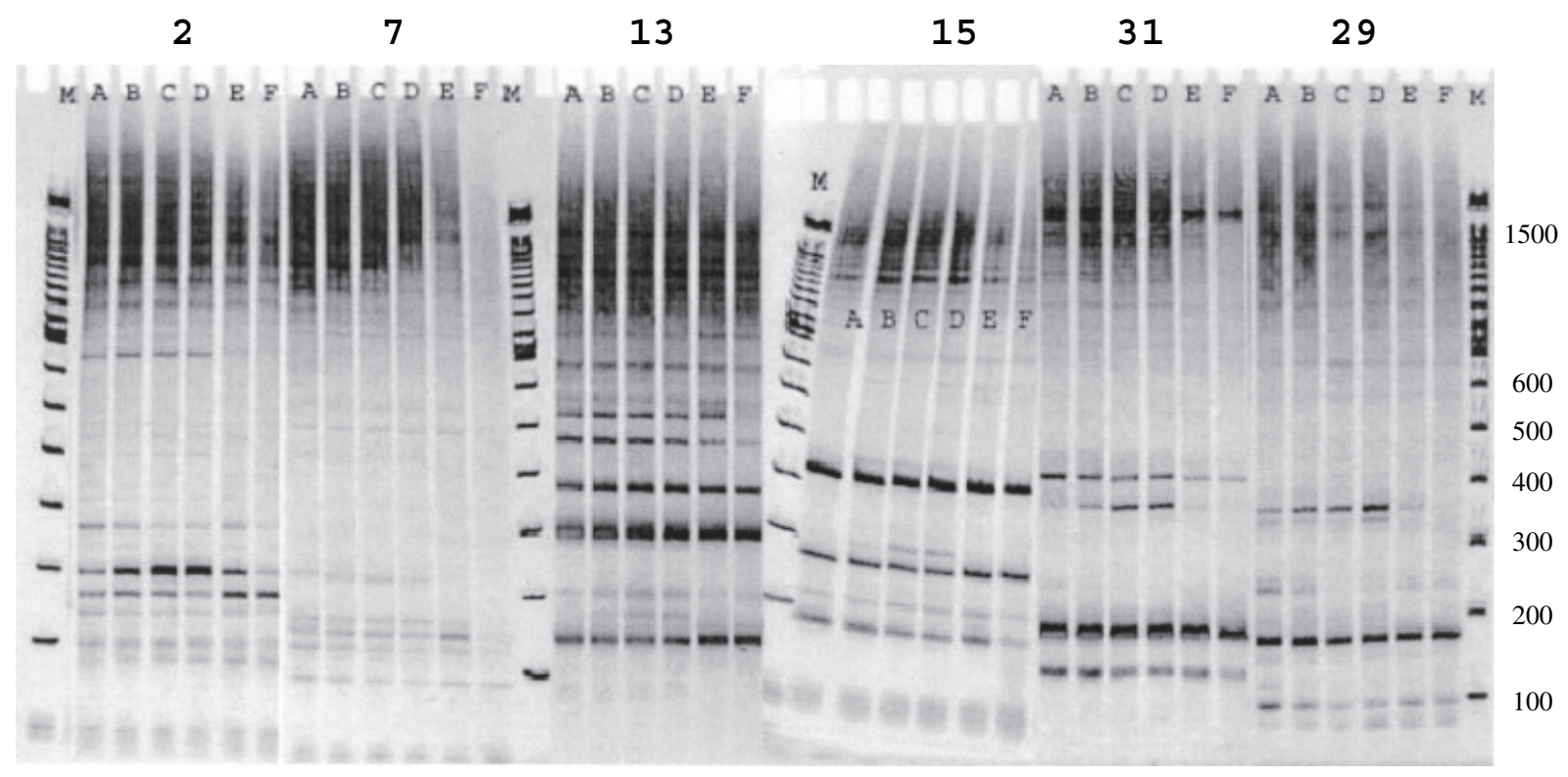

Fig. 1. Polyacrylamide gel analysis of $P$. gingivalis RFDD fragments. Each group of six lanes is the result of amplification with a single set of primers, designated by the number atop each group. Treatments from left to right: No treatment (a), $5 \min 42^{\circ} \mathrm{C} \mathrm{(b),} 10 \min 42^{\circ} \mathrm{C}(\mathrm{c}), 20 \mathrm{~min} 42^{\circ} \mathrm{C}(\mathrm{d}), 10 \mathrm{~min}$ $3.2 \mathrm{mM} \mathrm{H}_{2} \mathrm{O}_{2}$ (E), $20 \mathrm{~min} 3.2 \mathrm{mM} \mathrm{H}_{2} \mathrm{O}_{2}$ (F). 100 base pair intervals (beginning at 100 base pairs) nucleic acid size ladders in lanes 1, 15, 22, 41 (m). References to fragments in Table 1 can be observed by first finding the primer set number and then the approximate fragment size by comparison with the nucleic acid size ladders.

CA) fluorescent real time PCR instrument. The instrument software calculated the number of cycles, designated the $\mathrm{C}_{\mathrm{t}}$, required for the accumulated signal to reach a value 10 standard deviations above the value of the blank. Relative levels of expression of the target genes were calculated by normalizing the level of RNA gene-specific message in each tube with the level of $P$. gingivalis RNA expression added to each tube (5) and the relative increase or decrease of all samples targeted in the samples calculated as $2^{-\Delta \Delta \mathrm{Ct}}$. The statistical significance of the differences between treated and untreated cultures were determined by $t$-test using STATISTICA 6.0 (Statsoft, Tulsa, OK). Since there were nine values for each target the homogeneity of variance between the groups was tested using the Brown-Forsythe modification of the Levene test (4). The Accession numbering convention from TIGR Comprehensive Microbial Resource (http://www.tigr.org/tigr-scripts/ CMR2/GenomePage3.spl?database=gpg) annotated database was used to identify $P$. gingivalis genes, as described by Nelson et al. (25).

\section{Normalization genes for RT-PCR}

Evaluation of differential gene expression is highly dependent upon a reliable method for normalizing the RT-PCR data. For in vitro studies of short duration comparison of specific gene(s) expression and expression of $16 \mathrm{~S}$ rRNA genes are frequently used and seem to be appropriate for early to mid log phase growth (10). Preliminary experiments showed no change in the ratio of expression of $P$. gingivalis 16S rRNA cDNA compared to genomic DNA or cell number (36) during the 20 - or 30 -min incubation period with any of the environmental stressors (data not shown).

\section{Results}

Fragments from the silver-stained gels (Fig. 1) were chosen for further study based on their differential expression after treatment with either a $+5^{\circ} \mathrm{C}$ heat shock or oxidative stress. The selected genes represented a fraction of the genes differentially expressed among the approximately 800 clearly separated fragments on the six gels used to evaluate the RFDD experiment. Of the remaining genes, several were found to be duplicates. One pair of fragments representative of $\mathrm{PG}$ 1795, an apparent lipopolysaccharide-modifiable surface protein, was retained and the rest of the duplicates discarded. Blast searches of the $P$. gingivalis whole genomic sequence allowed us to identify the remaining 16 unique genes (Table 1).
When we examined the effects of heat shock on gene expression by QRT-PCR there were 12 of 16 genes that demonstrated a statistically significant increase in expression compared to untreated controls. One gene, $a b f D$, was significantly decreased and the remaining five genes did not change (Fig. 2). Exposure of $P$. gingivalis to atmospheric levels of oxygen resulted in statistically significant increases in five of the target genes. The expression of the remaining genes was unchanged from untreated levels (Fig. 2). Only a single gene, $\sec D F$, demonstrated increased expression in response to treatment of $P$. gingivalis with hydrogen peroxide. Seven of the genes demonstrated reduced expression and there was no change in the remaining eight (Fig. 2).

Several of the genes isolated were associated with outer membrane proteins and processing of the $P$. gingivalis Arggingipains. Among the gene products identified in our differential display were a porin (omp41, PG 0695), a lipopolysaccharide-modifiable surface protein (P27, PG1795) and a ribosomal protein S1 (rpsA, PG1297). We also identified increased expression of the $\operatorname{rgp} A$ (PG0506) and $\operatorname{rgpB}$ (PG2024) genes upon exposure to both heat and air stress. The HSP60 chaperone family representative in $P$. gingivalis PG0520 (groEL) 
Table 1. Genes identified by Restriction Fragment Differential Display. Gene accesssion numbers and gene designation are from the TIGR preliminary annotation database. Column 3 refers to results displayed in Fig. 1, where applicable $\left(^{*}\right)$. The first number indicates the primer set used for the original amplification and the number after the dash refers to the nucleotide base pair size of the fragment. Arrow direction indicates increase $(\uparrow)$ or decrease $(\downarrow)$ in expression

\begin{tabular}{|c|c|c|c|c|c|c|}
\hline \multirow[b]{2}{*}{ Gene } & \multirow{2}{*}{$\begin{array}{l}\text { TIGR Accession } \\
\text { Number }\end{array}$} & \multirow{2}{*}{$\begin{array}{l}\text { Location } \\
\text { on RFDD }\end{array}$} & \multirow[b]{2}{*}{ Gel function } & \multicolumn{3}{|c|}{$\begin{array}{l}\text { Significant }(P \leq 0.05) \text { change } \\
\text { in QRT-PCR gene expression } \\
\text { after treatment }\end{array}$} \\
\hline & & & & Heat & Air & $\mathrm{H}_{2} \mathrm{O}_{2}$ \\
\hline$\overline{\text { ISPg1 }}$ & PG0184 & $27-290$ & transposase & $\uparrow$ & & \\
\hline $\operatorname{infB}$ & PG0255 & $17-320$ & translation initiation factor IF-2 & $\uparrow$ & & \\
\hline $\operatorname{rpg} \mathrm{A}$ & PG0506 & $22-320$ & arginine-specific cysteine proteinase & $\uparrow$ & & \\
\hline groEL & PG0520 & $15-201^{*}$ & chaperonin, $60 \mathrm{kDa}$ & $\uparrow$ & $\uparrow$ & \\
\hline pyrG & PG0525 & $26-380$ & CTP synthase & $\uparrow$ & & \\
\hline abfD & PG0692 & $31-340 *$ & 4-hydroxy-CoA dehydratase & & & \\
\hline ompF & PG0695 & $7-215^{*}$ & immunoreactive antigen $\mathrm{P} 32$, porin & $\uparrow$ & & \\
\hline HYP2 & PG0774 & $4-170$ & hypothetical protein & & $\uparrow$ & \\
\hline epsC & PG1135 & $24-180$ & glycosyltransferase & & $\uparrow$ & \\
\hline rpsA & PG1297 & $2-110^{*}$ & ribosomal protein $\mathrm{S} 1$ & $\uparrow$ & & $\uparrow$ \\
\hline sod & PG1545 & $16-290$ & superoxide dismutase, Fe-Mn & $\uparrow$ & $\uparrow$ & \\
\hline humY & PG1551 & $31-180 *$ & HmuY protein & $\uparrow$ & & \\
\hline secDF & PG1762 & $13-200 *$ & protein-export membrane protein & $\uparrow$ & $\uparrow$ & $\uparrow$ \\
\hline HYP1 & PG1795 & $2-200 *, 29-350 *$ & $\begin{array}{l}43-64 \mathrm{kDa} \text { lipopolysaccharide-modified } \\
\text { protein }\end{array}$ & & $\uparrow$ & \\
\hline cysS & PG1878 & $19-140$ & cysteinyl-tRNA synthetase & $\uparrow$ & & \\
\hline $\operatorname{rpgB}$ & PG2024 & $25-180$ & Arginine protease ArgI polyprotein & $\uparrow$ & & \\
\hline
\end{tabular}

showed increased gene expression in the case of both heat shock and oxidative stresses, as did the sod (PG1545) gene (Fig. 2). Two other stress response genes, dnaK and $h t p G$, were added to the analysis, but were not recovered from the RFDD gels, and displayed increased expression.

Several genes involved in protein synthesis and trafficking were also activated. PG0255 (infB) is a translation initiation factor, IF2. We found it to be up-regulated in response to the heat shock, but substantially reduced in expression in response to oxidative shock. In addition, we found that heat stress induced increases in expression of $\sec D F$ (PG1762), a protein-export membrane protein, and cysteinyl-tRNA synthetase gene, cysS (PG1878). Both were down-regulated by oxidative shock.

\section{Discussion}

Several authors have described their results with other RNA expression-based methods and bacteria $(9,11-13,39)$. Here, we stimulated $P$. gingivalis with heat and oxidative shock, but other environmental stresses, including interaction with host cells, could be examined using this technique. Genes known to be involved in virulence were found in a relatively small sample of all genes differentially expressed on the RFDD gels. RFDD and other related methods are not as efficient as oligonucleotide microarray technology for bacterial species that have been completely sequenced, as have P. gingivalis, Fusobacterium nucleatum (15) and others.
However, many other oral bacteria will likely remain unsequenced for some time and mRNA display methods will continue to be useful.

Some genes that attracted our attention were also highlighted by Veith et al. (37) in their proteomic survey of outer membrane proteins and proteolytic processing of the $P$. gingivalis Arg-gingipains. Among the gene products they identified that we found in our differential display were a porin (omp41, PG 0695), an lipopolysaccharidemodifiable surface protein (P27, PG1795) and a ribosomal protein $\mathrm{S} 1$ ( $r p s A, \mathrm{PG} 1297)$. They also identified major fragments of the $\operatorname{rgp} A$ and $\operatorname{rgp} B$ gene products, as we did. These authors and others $(29,31)$ have suggested that the Arg-gingipains may use lipopolysaccharide as a surface anchor, based on an association between the molecules. The induction of $\operatorname{rpg} A$ and $\operatorname{rpg} B$ by heat stress of $+2^{\circ} \mathrm{C}$ has been described by others (32). The transcriptional increase observed in these experiments is in agreement with both those findings.

Three of the genes identified by RFDD may be involved in lipopolysaccharide biosynthesis, which may be required in situations where $\operatorname{rpg} A$ is up-regulated. It has been suggested that the ompF-coded porin protein is involved in lipopolysaccharide transport (38). A search of the COG (http://www.ncbi.nlm.nih.gov/COG/) database at NCBI found numerous highly significant hits for the sequence of the epsC and COG 2138 family of glucosyltransferase enzymes involved in lipopolysaccharide synthesis in other bacteria. Further, it has been suggested that in some bacteria, when demand for lipopolysaccharide is high, a pathway utilizing CTP synthetase is activated (40). In our experiments we found that ompF (41 kDa outer membrane protein) and pyrG (CTP synthetase) were elevated when $\operatorname{rpg} A$ was also increased, which could signal the need for more lipopolysaccharide attachment sites on the outer membrane of $P$. gingivalis.

There was differential expression of IF2 (inf $B$ ) in response to the environmental stressors used in these experiments. During initiation of protein synthesis in bacteria, translation initiation factor IF2 is responsible for the recognition of the initiator tRNA (fMet-tRNA). To perform this function, IF2 binds to the ribosome interacting with both $30 \mathrm{~S}$ and $50 \mathrm{~S}$ ribosomal subunits (18). It has also recently been reported that IF2 has chaperone properties that allow it to re-nature a number of proteins after stresses (6). Whether it is performing such a function in response to the $+5^{\circ} \mathrm{C}$ heat shock is not clear from this data, and multiple functions may be required of the $\inf B$ gene in those situations.

Previous studies $(19,22)$ have reported that oxidative shock does not activate the $P$. gingivalis stress proteins GroEL and DnaK. Both of these reports used methods that measure the increase in the protein, Western Blots and 2-dimensional gels. Here we observed that at least in the time frame we used, all three of the major chaperone genes of $P$. gingivalis ( $g r o E L$, $d n a K$, and $h t p G$ ) were up-regulated in response to heat shock of $+5 \mathrm{C}$ and oxidative shock. It has recently been 


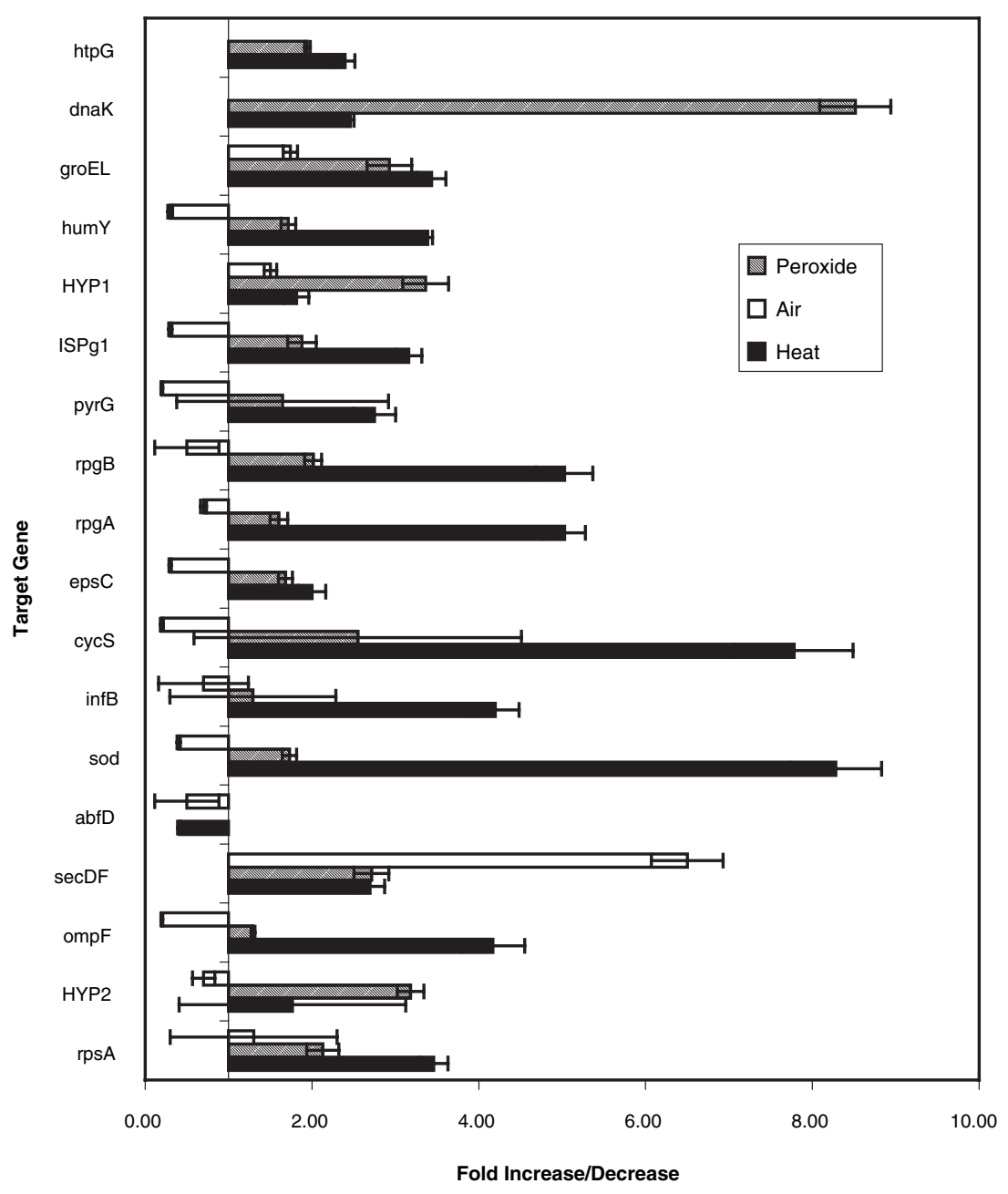

Fig. 2. Effect of environmental stress on $P$. gingivalis gene expression. Fold increase in mRNA expression determined by QRT-PCR of fragments from cells treated for 30 min with $3.2 \mathrm{mM} \mathrm{H}_{2} \mathrm{O}_{2}$ (Peroxide), shaking in atmospheric oxygen levels (Air) or $+5^{\circ} \mathrm{C}$ heat shock (Heat). If there was no difference in expression between untreated and treated cells, the fold increase/decrease value was 1.0. Fold increase/decreases are the means of nine determinations \pm SEM. Asterisks $(*)$ indicate a significant change from no treatment control for each primer set $(P \leq 0.05, t$-test).

demonstrated that the transcription of at least the GroEL chaperone mRNA gene rises rapidly upon stimulation with atmospheric $\mathrm{O}_{2}$ but that transcription levels return to normal within $4 \mathrm{~h}$ (Biqing $\mathrm{Lu}$, personal communication), which may account for the differences in these reports.

As seen by others, we observed little response, other than toxicity, to treatment with hydrogen peroxide (23). It has recently been shown that while superoxide dismutase is important in the relative aerotolerance of $P$. gingivalis, the decoration of the cells' surface with hemin-derived molecules is probably the bacterium's most important method of dealing with hydrogen peroxide (33).

These results support the notion that environmental stresses increase both lipopolysaccharide and Arg-gingipain synthesis, important virulence-related factors
mRNA (including epsC) are probably an important part of the response to environmental stresses. All in all, these results emphasize the need for studies to measure the coordinated responses of bacteria like $P$. gingivalis, which use a multitude of interrelated metabolic activities to survive the environmental hazards of the infection process.

\section{Acknowledgments}

The technical assistance of Mr. Taniform Abongawa is appreciated. P. gingivalis sequencing was accomplished with support from the National Institute of Dental and Craniofacial Research (NIDCR), part of the National Institutes of Health (NIH) in collaboration with The Forsyth Institute. An award from the National Institutes of Health and NIDCR (DE11117) and 3M supported our work. RFDD-PCR is a patented process (PCT/DK98/00186). This work was partially presented in abstract (J Dent Res 2000: 79: 234).

\section{References}

1. Abaibou H, Chen Z, Olango GJ, Liu Y, Edwards J, Fletcher HM. vimA gene downstream of recA is involved in virulence modulation in Porphyromonas gingivalis W83. Infect Immun 2001: 69: 325-335.

2. Altschul SF, Gish W, Miller W, Myers EW, Lipman DJ. Basic local alignment search tool. J Mol Biol 1990: 215: 403-410.

3. Bachem CW, van der Hoeven RS, de Bruijn SM, Vreugdenhil D, Zabeau M, Visser RG. Visualization of differential gene expression using a novel method of RNA fingerprinting based on AFLP: analysis of gene expression during potato tuber development. Plant J 1996: 9: 745-753.

4. Brown MB, Forsythe AB. Robust tests for the equality of variances. J Am Statist Assoc 1974: 69: 264-267.

5. Bustin SA. Absolute quantification of mRNA using real-time reverse transcription polymerase chain reaction assays. J Mol Endocrinol 2000: 25: 169-193.

6. Caldas T, Laalami S, Richarme G. Chaperone properties of bacterial elongation factor EF-G and initiation factor IF2. J Biol Chem 2000: 275: 855-860.

7. Chen $\mathrm{T}$, Dong $\mathrm{H}$, Yong $\mathrm{R}$, Duncan MJ. Pleiotropic pigmentation mutants of Porphyromonas gingivalis. Microb Pathog 2000: 28: 235-247.

8. Curtis MA, Aduse-Opoku J, Rangarajan M. Cysteine proteases of Porphyromonas gingivalis. Crit Rev Oral Biol Med 2001: 12: 192-216.

9. Du LD, Kolenbrander PE. Identification of saliva-regulated genes of Streptococcus gordonii DL1 by differential display using random arbitrarily primed PCR. Infect Immun 2000: 68: 4834-4837.

10. Eleaume H, Jabbouri S. Comparison of two standardisation methods in real-time 
quantitative RT-PCR to follow Staphylococcus aureus genes expression during in vitro growth. J Microbiol Methods 2004: 59: $363-370$

11. Frandsen EV, Poulsen K, Curtis MA, Kilian M. Evidence of recombination in Porphyromonas gingivalis and random distribution of putative virulence markers. Infect Immun 2001: 69: 4479-4485.

12. Gravesen A, Sorensen K, Aarestrup FM, Knochel S. Spontaneous nisin-resistant Listeria monocytogenes mutants with increased expression of a putative penicillin-binding protein and their sensitivity to various antibiotics. Microb Drug Resist 2001: 7: 127-135.

13. Gravesen A, Warthoe P, Knochel S, Thirstrup K. Restriction fragment differential display of pediocin-resistant Listeria monocytogenes 412 mutants shows consistent overexpression of a putative beta-glucosidespecific PTS system. Microbiology 2000: 146 (6): 1381-1389.

14. Grenier D, Belanger M. Protective effect of Porphyromonas gingivalis outer membrane vesicles against bactericidal activity of human serum. Infect Immun 1991: 59: 3004-3008.

15. Hintermann E, Haake SK, Christen U, Sharabi A, Quaranta V. Discrete proteolysis of focal contact and adherens junction components in Porphyromonas gingivalis-infected oral keratinocytes: a strategy for cell adhesion and migration disabling. Infect Immun 2002: 70: 58465856.

16. Kapatral V, Anderson I, Ivanova N, Reznik $\mathrm{G}$, Los T, Lykidis A, et al. Genome sequence and analysis of the oral bacterium Fusobacterium nucleatum strain ATCC 25586. J Bacteriol 2002: 184: 2005-2018.

17. Lamont RJ, Jenkinson HF. Life below the gum line: pathogenic mechanisms of Porphyromonas gingivalis. Microbiol Mol Biol Rev 1998: 62: 1244-1263.

18. La Teana A, Gualerzi CO, Dahlberg AE. Initiation factor IF 2 binds to the alphasarcin loop and helix 89 of Escherichia coli 23S ribosomal RNA. RNA 2001: 7: 11731179.

19. Leke N, Grenier D, Goldner M, Mayrand D. Effects of hydrogen peroxide on growth and selected properties of Porphyromonas gingivalis. FEMS Microbiol Lett 1999: 174: 347-353.

20. Lopatin DE, Combs A, Sweier DG, Fenno JC, Dhamija S. Characterization of heatinducible expression and cloning of $\mathrm{HtpG}$ (Hsp90 homologue) of Porphyromonas gingivalis. Infect Immun 2000: 68: 1980 1987.
21. Lopatin DE, Jaramillo E, Edwards CA, Van Poperin N, Combs A, Shelburne CE. Cellular localization of a Hsp90 homologue in Porphyromonas gingivalis. FEMS Microbiol Lett 1999: 181: 9-16.

22. Lu B, McBride BC. Stress response of Porphyromonas gingivalis. Oral Microbiol Immunol 1994: 9: 166-173.

23. Lynch MC, Kuramitsu HK. Role of superoxide dismutase activity in the physiology of Porphyromonas gingivalis. Infect Immun 1999: 67: 3367-3375.

24. Maeda H, Miyamoto M, Hongyo H, Nagai A, Kurihara H, Muryama Y. Heat shock protein 60 (GroEL) from Porphyromonas gingivalis. molecular cloning and sequence analysis of its gene and purification of the recombinant protein. FEMS Microbiol Lett 1994: 124: 121-122.

25. Nelson KE, Fleischmann RD, DeBoy RT, Paulsen IT, Fouts DE, Eisen JA, et al. Complete genome sequence of the oral pathogenic Bacterium porphyromonas gingivalis strain W83. J Bacteriol 2003: 185: 5591-5601.

26. O'Brien-Simpson NM, Black CL, Bhogal PS, Cleal SM, Slakeski N, Higgins TJ, et al. Serum immunoglobulin $\mathrm{G}$ (IgG) and $\mathrm{IgG}$ subclass responses to the RgpA-Kgp proteinase-adhesin complex of Porphyromonas gingivalis in adult periodontitis. Infect Immun 2000: 68: 2704-2712.

27. O'Brien-Simpson NM, Paolini RA, Hoffmann B, et al. Role of RgpA, RgpB, and Kgp proteinases in virulence of Porphyromonas gingivalis W50 in a murine lesion model. Infect Immun 2001: 69: 7527-7534.

28. Rocha ER, Owens G Jr, Smith CJ. The redox-sensitive transcriptional activator OxyR regulates the peroxide response regulon in the obligate anaerobe Bacteroides fragilis. J Bacteriol 2000: 182: 5059-5069.

29. Shoji M, Ratnayake DB, Shi Y, Kadowaki T, Yamamoto K, Yoshimura F, et al.. Construction and characterization of a nonpigmented mutant of Porphyromonas gingivalis: cell surface polysaccharide as an anchorage for gingipains. Microbiology 2002: 148: 1183-1191.

30. Slakeski N, Cleal SM, Bhogal PS, Reynolds EC. Characterization of a Porphyromonas gingivalis gene $p r t K$ that encodes a lysinespecific cysteine proteinase and three sequence-related adhesins. Oral Microbiol Immunol 1999: 14: 92-97.

31. Slaney JM, Rangarajan M, Aduse-Opoku J, Fawell S, Darby I, Kinane D, et al. Recognition of the carbohydrate modifications to the RgpA protease of Porphyromonas gingivalis by periodontal patient serum IgG. J Periodontal Res 2002: 37: 215-222.30.
32. Smalley JW, Birss AJ, Percival R, Marsh PD. Temperature elevation regulates iron protoporphyrin IX and hemoglobin binding by Porphyromonas gingivalis. Curr Microbiol 2000: 41: 328-335.

33. Smalley JW, Birss AJ, Silver J. The periodontal pathogen Porphyromonas gingivalis harnesses the chemistry of the mu-oxo bishaem of iron protoporphyrin IX to protect against hydrogen peroxide. FEMS Microbiol Lett 2000: 183: 159-164.

34. Tanner A, Maiden MF, Macuch PJ, Murray LL, Kent RL Jr. Microbiota of health, gingivitis, and initial periodontitis. J Clin Periodontol 1998: 25: 85-98.

35. Tokuda M, Duncan M, Cho MI, Kuramitsu HK. Role of Porphyromonas gingivalis protease activity in colonization of oral surfaces. Infect Immun 1996: 64: 40674073.

36. Vandecasteele SJ, Peetermans WE, Merckx $R$, Van Ranst M, Van Eldere J. Use of gDNA as internal standard for gene expression in staphylococci in vitro and in vivo. Biochem Biophys Res Commun 2002: 291 528-534.

37. Veith PD, Talbo GH, Slakeski N, Dashper SG, Moore C, Paolini RA, et al. Major outer membrane proteins and proteolytic processing of RgpA and Kgp of Porphyromonas gingivalis W50. Biochem J 2002: 363: 105-115.

38. Veith PD, Talbo GH, Slakeski N, Reynolds EC. Identification of a novel heterodimeric outer membrane protein of Porphyromonas gingivalis by two-dimensional gel electrophoresis and peptide mass fingerprinting. Eur J Biochem 2001: 268: 4748 4757.

39. Wu Y, Lee SW, Hillman JD, Progulske-Fox A. Identification and testing of Porphyromonas gingivalis virulence genes with a pPGIVET system. Infect Immun 2002: 70 928-937.

40. Wylie JL, Berry JD, McClarty G. Chlamydia trachomatis CTP synthetase: molecular characterization and developmental regulation of expression. Mol Microbiol 1996: 22: 631-642.

41. Xie H, Cai S, Lamont RJ. Environmental regulation of fimbrial gene expression in Porphyromonas gingivalis. Infect Immun 1997: 65: 2265-2271.

42. Yoshida A, Nakano Y, Yamashita Y, Oho T, Shibata Y, Ohishi M, et al. A novel dnaK operon from Porphyromonas gingivalis. FEBS Lett 1999: 446: 287-291.

43. Zhang J, Dong H, Kashket S, Duncan MJ IL-8 degradation by Porphyromonas gingivalis proteases. Microb Pathog 1999: 26: 275-280. 